\title{
A nemzeti nyelv problematikájáról nyelvtörténeti, népköltészeti és fordításelméleti kontextusban
}

\section{Elöljáróban}

Tanulmányomban a népköltészet és a szépirodalom, valamint a nyelvtörténet (föleg a nyelvrokonság) köré fonódó diskurzusokat vizsgálom a nyelv standardizálásával és a nyelvújítással kapcsolatos elméleti viták tükrében a 19. század derekán megjelent két sajtótermékben, a Szépirodalmi Figyelóben és a Koszorúban. A magyar nyelvújítás sikerességének megítélése, az egységes irodalmi nyelv megalkotása, a népköltészet értékké emelkedése, a népi és az elit irodalmi stílus idealizált elegyének létrehozása sok szálon kapcsolódtak össze, több ponton a nyelvrokonság kérdésével is kiegészülve. Nem célom a korszak magyar nyelvre vonatkozó elméleti vitáinak széles körü áttekintése, az meg is haladná egy tanulmány kereteit. A főbb szempontokat az akkoriban bontakozó finnugor nyelvészet és a folklorisztikai kutatások elözményeként fontos események összefüggésében próbálom megragadni, tehát a folklorista és finnugor nyelvész perspektívájából kívánok áttekinteni néhány fontos kérdéskört, amely az értelmiség érdeklödésének homlokterébe került a vizsgált korszakban. Választásom azért esett az Arany János által szerkesztett két folyóiratra, mert szerzői között jelen vannak a magas irodalom képviselöi, a népköltészet gyüjtői és közreadói és a tudományos irodalom közvetítői is, akiknek köszönhetően (többek között) a nyelvtudomány aktuális eredményeiről naprakész lehetett, továbbá a magyar és külhoni népköltészeti alkotásokba is folyamatos betekintést nyerhetett a lelkes olvasóközönség. Mivel mindkét folyóirat tartalmaz visszatekintő írásokat, például Kazinczy nyelvújításáról, tanulmányom időbeli keretei a címben megadottnál természetesen tágabbak, a fö forrásanyag keletkezési ideje azonban a század közepére tehetö (1860-1865).

\section{A vizsgálat forrásanyagáról}

Joggal merülhet fel a kérdés, mennyire mutat a kor nagy, átfogó, föként a magyar nyelvet érintő diskurzusairól releváns képet egyetlen szerkesztő két, időben egymást követő sajtóorgánuma. A kor sajtókiadási gyakorlatára jellemző volt, hogy a különböző folyóiratok közel azonos időben megjelent lapszámai sok kereszthivatkozást tartalmaztak. Így például az Arany János keze alól kikerült adott lapszám olvasói számos más periodika írásaiba (pl. a Budapesti Szemle, Akadémiai Értesitö, Magyar Nyelv, Nyelvtudományi Közlemények) is beleláthattak vagy részletes ismertetés, vagy egy adott cikk átvétele révén, gyakorlat volt ugyanis máshol megjelent írások teljes terjedelmü közlése is (másodközlésként). A Szépirodalmi Figyelóben és a Koszorúban végig megfigyelhető az akadémiai hírek és a fontosabb kulturális események folyamatos közvetítése és értékelése. Az irodalmi (és részben népmüvelési) periodikák tehát nagyon jól használható forrásai a magyar nyelv standardizálási folyamatainak a vizsgálatához, nemcsak azért, mert már Kölcsey is az irodalmon keresztül kívánta megvalósítani a magyar nyelv reformját, hanem azért is, mert az irodalom akkoriban (és még hosszú évtizedeken át) „saját ügyének érezte” a nyelv vizsgálatára vonat- 
kozó paradigmákat. ${ }^{1}$ A nyelvi (mai értelemben nyelvtudományi) és irodalmi problematika szoros kapcsolódásáról nyilatkozott több alkalommal a Szépirodalmi Figyelö és a Koszorú szerkesztőjeként Arany János is: „Van-e helye széptani folyóiratban e nemü fejtegetésnek? A kérdésre egy másik kérdésben adok feleletet. Szükséges-e, hogy a szép tudományokkal, kivált pedig a költészettel foglalkozó egyén a nyelv sajátságiba is minél avatottabb legyen? (...) Igen" (Arany, SzF 1861/38: 593).

A nyelvészet és az irodalom fókuszában tehát egyaránt a magyar nyelv - akkoriban erősen nemzeti - ügye állt. Másrészt a népnyelvnek ${ }^{2}$ és a népköltészetnek az irodalmi szférába emelése is ebben a korszakban vált központi ideológiává, miként a népkarakterológia népköltészet által történő vizsgálhatósága is. ${ }^{3}$ A 18 . század második felétől kezdődően elindult, majd a 19. század folyamán a nacionalizmus és a romantika párhuzamos térhódításával kiteljesedett az a felfogás, miszerint a nemzet és a nemzeti nyelv léte feltételezik egymást (szemben a korábbi természetes nyelvi, nemzetiségi sokszínüséggel és a latin vagy a német - de akár egyes régiókban a magyar - nyelvhasználat közéleti szerepének természetességével, a közlekedő nyelvek második anyanyelvként kezelésével). A magyar nyelv státuszának emelkedésével egyszerre teremtődött meg a nyelvújításnak, a nyelvmüvelésnek, valamint az irodalom megújításának a feltétele és szükségessége a külföldi müvekre és a népiességre is építve. Következésképpen a nyelvi, irodalmi, esztétikai viták és nézetek át- és átszőtték a szellemi elit diskurzusait, és lassanként áthatották a magyar társadalmat, ezáltal hozva létre egy új - máig ható - törésvonalat a magyar anyanyelvüek és a „nemzetiségek” között (ez a folyamat az utóbbiak körében is sorra megindult).

A Szépirodalmi Figyelőnek 156 (1860 novemberétől 1862 októberéig), a Koszorúnak pedig összesen 130 száma jelent meg 1863. januárjától 1865. júniusáig (HászFehér 2016: 25). Az előbbi kicsit szükebb tematikájú, szükebb olvasóközönséget célzó lap volt, míg az utóbbit az irodalom és a magyar nyelv központi szerepe mellett Arany színesebb tematikával, az ismeretterjesztés és népmüvelés szándékával szélesebb közönség számára indította útjára. Az arculatváltást fémjelzi a Koszorú alcíme is: „Szépirodalmi s általános miveltség terjesztő hetilap”. Ennek szellemében az Koszorúban megjelenő írások a kultúra és a tudomány területeiről is tág merítést adtak, ezen felül Arany János teret engedett az elméleti vitáknak is a folyóirat hasábjain. Ezek az elméleti viták gyakran vették célba a magyar nyelv ügyét, legyen szó nyelvrokonságról, a nyelvújítás ügyéről vagy a nyelv strandardizálásáról. Ami ezen

1 Ez a kettősség még a 20. század első évtizedeinek tudományos szemléletében is egyértelműen kimutatható. Az 1913-ban megjelent magyar irodalomtörténet első fejezetében például a következő sorokat olvashatjuk: „Minden nemzetnek legjellemzőbb tulajdona, legféltettebb kincse, legnagyobb büszkesége a nemzeti nyelv. S a nyelvvel oly szoros kapcsolatban vannak a népnek lelki tulajdonságai, művelödése mozzanatai, s különösen az irodalom fejlődése, hogy az irodalomtörténet bevezetésében méltán foglalhat helyet a nyelv eredetének és történetének vázlata" (Simonyi 1913: 1).

2 A népnyelv meghatározását Tolcsvai Nagy Gábortól kölcsönzöm, és tanulmányom egészében ebben az értelemben használom: „népnyelv mint a magyar nyelvjárások teljessége, illetve egy abból már a 19. században elvont általánosabb magyar, paraszti nyelv(változat)" (Tolcsvai Nagy 2010: 14).

3 Ennek a gondolatnak a felmerülése természetesen jóval régebbi. Már Sylvester János 16. századi Újtestamentumának egyik jegyzetében megtaláljuk megfogalmazását: „melyekben [értsd: a virágénekekben] csudálhatja minden níp az magyar nípnek elmíjinek éles voltát az lelísben, mely nem egyéb, hanem a magyar poézis" (idézi Simonyi 1913: 1). 
írások müfaját illeti, a 19. század közepén kibontakozó esszé bizonyult a legalkalmasabb formai keretnek az új ismeretek ismeretterjesztő jellegü, ám mégis magas színvonalú, igényes tolmácsolásához. Az esszéírói gyakorlatban tehát a tudomány és az irodalom szerencsésen összetalálkozott, ahogyan ezt gróf Mikó Imre is megfogalmazta a Koszorút útjára indító első számban:

„Tiszta nyelv és irály, alapos tárgyalási mód, higgadt és elvek körül járó vita; mindenek fölött pedig oly előadás, hogy a tudomány komolyságát ennek vonzatossága mérsékelje, az elméletek elvontságát az elöadás természetes könnyüsége s némi költöiesség elevenítse" (Mikó, K 1863/I., 1: 2-3).

\section{Nyelvmüvelés a magyar nyelv eredetének, rokonításának a tükrében}

Tény, hogy a nyelvrokonság a vizsgált folyóiratokban nem tartozott a központi jelentőségü témák közé, ugyanakkor sokszor elválaszthatatlanul összeforrt a standardizálás, a nyelvmüvelés problematikájával. A nyelvújítás viszont teljes cikksorozatot kap a Figyelóben Kazinczy nyelvújítása címmel, Imre Sándor tollából. A Figyelö és a Koszorú hasábjain az akadémiai híreken, a finnugor népek népköltészetének bemutatásán keresztül, valamint az irodalmi és népi stílussal, müfordításokkal foglalkozó írások révén a század első feléhez viszonyítva jóval összetettebb, ugyanakkor a régebbi irányvonalakat is folytató diskurzus bontakozott ki. A terjedelmes esszéken, kritikákon, vitákon túl igyekszem figyelembe venni egy-egy rövid megnyilatkozást, elejtett vagy közbeszúrt megjegyzést, lábjegyzetet is, hiszen mindezekből együttesen nyerhetünk betekintést abba, hogyan vélekedett a korabeli értelmiség a magyar nyelv és irodalom helyzetéröl, illetve annak jobbítására és felemelésére szolgáló törekvésekröl. Arany nyitottságát mutatja, hogy bár a kölcsönös tiszteletre és józan érvelésre épülő vitától távol eső, elfogadhatatlan vagy sértő stílust, a negatív szélsőségeket kizárva, de egymással szembenálló nézeteket, nyilvános vitákat is közölt, többnyire hosszú, több lapszámon átívelő sorozatokban. Támogató és erösen kritikus vélemények fogalmazódtak meg a nyelvújítás sikerességéről is, akárcsak az irodalmi müvek fordításáról vagy a magyar írók müveinek fogadtatásáról. Mindebben tetten érhető Kazinczy szellemisége, a stílus, az ízlés formálásában érzett küldetéstudat: „elegáns, energikus, új zengésü szólás”4 és az irányzatok közötti higgadt és bölcs kommunikáló elösegítése. ${ }^{5}$

4 KFL III. 304.

5 Utóbbit jól példázza Kazinczy Révaihoz füződő viszonya, amelynek egyik aspektusát Miskolczy Ambrus így jellemezte: „Kazinczy kritikai szenvedélyét és egyéni ellenszenveit is igyekezett alárendelni valamiféle szenvtelen tárgyilagosságnak, és olykor még korábbi nézeteit is helyesbítette. Nem értett egyet azzal, hogy Révai Miklós a nyelv eredeti állapotát akarta visszaállítani, és ennek rendelte alá forráskiadó tevékenységét. Viszont Kazinczy maga is ápolta a régi magyar irodalmat, és elfogadta Révai Miklós nyelvtörténetileg megalapozott szóelemző helyesírási szabályait, jottista volt az ejtéshez való igazodást hirdető ipszilonista többség ellenében. (Látja - írja a jottista, míg az ipszilonista szerint az ejtéshez igazodó helyes alak: láttya. Az ipszilonista a közérthetőségre hivatkozott, csakhogy ez csalóka is lehet, mert mint Kazinczy mérgesen tette szóvá, lánya a hont hony-nak ejtette, 


\begin{abstract}
„A közönség izlését minden pedánsság nélkül nevelni, szigorúan birálni a nélkül, hogy a biráló egy klik szolgálatába szegődnék, vagy a szerzőt sértené: ez volt a két lap kitüzött és bizonyos fokig (a mennyire a rövid idő és a viszonyok korlátai megengedték) el is ért czélja. Arany személyisége különben is igen alkalmatos volt ily biráló tisztre: szelíd, de határozott modora, az utánérzés, a sympathia tehetsége nagy költői tudatossággal párosulva, izlése meg tapintata egyaránt arra hivatták, hogy a szépirodalomban judex curiae legyen" (Riedl 1887: 249).
\end{abstract}

A kor polihisztora, Brassai Sámuel élesen megfogalmazott kritikáiban elöfordultak sarkosabb vélemények, negatív értékítéletek, (természetesen másoknál is), ám Arany ezekben az esetekben szerkesztői megjegyzésekben finomította a vita élét (lásd pl. SzF 1860/30, 466, 467.).

Amiért a nyelvrokonság kérdéskörét is be kell vonni a magyar nyelv standardizációjának diskurzusába, az az a tény, hogy a Figyelö és a Koszorú kiadásának időszakára a finnugor nyelvek és népek kutatásában minden korábbinál jelentősebb, társadalmi visszhangot is kiváltó eredmények születtek, és ezekre gyorsan reflektált a tudományos és a tágabb közvélemény is. A Reguly által gyüjtött, akkoriban tényleg szenzációnak számító nyelvi és etnográfiai adatokról gyakran szó esett értelmiségi körökben. Arany János már a Koszorúban is nagy figyelmet fordított arra, hogy Reguly munkásságának kellő visszhangot adjon. ${ }^{6}$ Ebben a korszakban, az alapos gyüjtőutaknak köszönhetően valósult meg a különböző finnugor és török nyelvek részletes leírása, és ezzel párhuzamosan egyre pontosabb összehasonlító módszerek kidolgozására nyílt lehetőség. Érthető, hogy a rokonság a magyar nyelv tágabb ügyének is fontos részévé vált. A korszak kiemelkedő nyelvésze, Hunfalvy Pál, Reguly hagyatékának első gondozója mind saját kutatásaival, mind a Regulykéziratok közlésével a figyelem középpontjában állt. ${ }^{7}$

Arany életmüvét tanulmányozva is szépen kibontakozik, mennyi szálon kapcsolódik a nyelv eredetének tanulmányozása az irodalmi, illetve tudományos nyelv kialakításához a 19. század második felében. A szárnyait sikeresen bontogató finnugor

mert honja helyett honnya alakot olvasott.) Kazinczy a legnagyobb rokonszenvvel figyelte, ahogy Révai kiadja a régi magyar irodalom klasszikusait, régi szavakat felelevenít, de amíg Révai a nyelvszokást akarta normává emelni, Kazinczy a szóalkotás szabadságához ragaszkodott. A nyelvtudósnak és a nyelvtudós emlékének kijáró tisztelet miatt a konfliktus elmaradt" (Miskolczy 2010: 25).

6 A Reguly Antal hagyományai című sorozat indítójaként $A$ vogul föld és nép (1864) címmel, Hunfalvy Pál szerkesztésével és feldolgozásával megjelent kötetről a Koszorú nagy részletességgel, folytatásokban három egymást követő lapszámban számolt be (K 1865/I., 2: 42-44; 1865/I., 3: 64-66; 1865/I., 4: 90-91).

7 Amikor a korabeli értelmiség nyelvrokonságról alkotott véleményét vizsgáljuk, természetesen figyelembe kell venni, hogy az 1880-as évek elején kibontakozó ugor-török vita előtt a kétféle származtatás nem került egymással éles ellentétbe. Ezzel összefüggésben a korabeli tudományosságra jellemző volt a török és a finnugor nyelvekben való jártasság együttes megléte. Munkácsi Bernát egyetemi tanulmányai alatt Budenz Józsefnél nemcsak finnugor nyelveket, hanem például jakutot is hallgatott, Vámbéry Árminnál pedig csuvas nyelvi tanulmányokat folytatott. A csuvas nyelvet pedig Vámbéry a finnugorkutatás egyik emblematikus alakjának, Reguly Antal helyszíni nyelvészeti jegyzetei alapján tanította. 
nyelvtudomány eredményeit az értelmiség meghatározó része a magyar tudomány sikereként könyveli el, amely a hazai tudományos élet nívóját és a magyar nyelv értékét olyan magasra emeli, hogy méltán érdemli meg a nyugati tudóskörök figyelmét és elismerését. A nyelvrokonságot, nyelvtörténetet már Kazinczy is belevette az érvelésébe, még ha teljesen más kontextusban is. Nyilvánvaló, hogy a keleti örökség és az európaiság, a magyar nemzet aktuális érdekeinek megfogalmazásában sokszor megjelent toposzként a nyelv eredete és rokonsága. Miskolczy Ambrust idézve Kazinczy „,[ú]gy állította be az idegen szavak ellenében csak magyarokat használni akaró puristákat, mint akik Ázsiába vezetnek vissza, ahelyett, hogy a nyugati müvészetek: építészet, festészet, zene kincseire figyelnének, és ezért »azoknak a Dón felé szerencsés utat s gazdag zsákmánnyal megérkezést« kívánt” (Miskolczy 2010: 26). ${ }^{8}$ A nyelv- és nemzetszemlélet elválaszthatatlansága több síkon is megragadható. A diakrón, azaz nyelvtörténeti, nyelvrokonsági dimenzió mellett a nyelv szinkrón felfogása is plasztikusan összekapcsolódik a társadalommal, ahogyan azt Csokonai szimbolikus leírásában is olvashatjuk: „Én a szókat úgy nézem a nyelvben, mint a polgárokat a hazában" (Harsányi-Gulyás 1922: 628). Ennek értelmében egyes szavak ,régi törzsökös eredetüek”, mások, mint például a jövevényszavak, vándorszók „pecsétes levelet kaptak”, „hungarizáltattak”. (Harsányi-Gulyás 1922: 629). Visszakanyarodva a Figyelö és a Koszorú írásaihoz, azokban szintén többsíkú értelmezésre van lehetőség. Érdekes, új adalék a finnugor nyelvészet tudománytörtéhez is az a többször is megfogalmazott (és fentebb általam is említett) elgondolás, miszerint Arany János a magyar nyelv európai megbecsüléséhez, a magyar tudományosság elismeréséhez kitünő eszköznek tartotta az uráli nyelvrokonság kutatásának az eredményeit. A „nyelvtudományi nagyjutalomról” szóló beszámolójában Hunfalvy Pál a Kondai Vogul Nyelv címü munkájáról (1872) így ír: „egy eddigelé előttünk ismeretlen nyelv világába tekinthetünk, s ami ránk nézve fö, oly nyelvébe, mely a magyarhoz közelrokonnak bizonyult be". Továbbá:

„E munka [...] hosszan tartó fáradságos tanulmány gyümölcse, alapos kutatások eredménye [...] a magyar összehasonlító nyelvtudomány anyagát tetemesen szaporítva, annak sikeres buvárlatát jóval megkönnyítette, [...] a magyar tudományosságnak nem csekély tiszteletet fog szerezni a külföld elött is" (AJÖM XIV: 477). [Kiemelés: T. I.]

„A nyelvtudomány mezején bennünket legközelebb a magyar s ezzel rokon nyelvek tudománya érdekel. Nemcsak azért, mert az Akadémia már létét is ez eszmének, a magyar nyelv kimüvelése eszméjének, köszöni [...] hanem a kiváló szerepnél fogva is, mely ez által nekünk jut osztályrészül a tudományos világ concertjében. Az altái hasonlitó nyelvtudomány mezején egyik nyugoti nép sincs, se hivatva, se képesitve oly eredményekhez jutni, mint épen $m i$ - bár eddig csupán egy-két nyelvtudósunk buzgalma által - már is eljutottunk. A vogul, a cseremiz, a mordvin stb. nyelvben tett magyar kutatások már is előbbre vitték az altái nyelvek tudományát; ez évben pedig, a nyelvtudományi bizottság aegise alatt, fáradhatatlan tudósunk Hunfalvy Pál, kinek múlt öszi felszólamlása a londoni congressuson meglepte a nyelvész világot, az osztják nyelv grammatikáját és szótárát búvárlotta és adta ki, fordított és eredeti szövegekkel kisérve; Budenz Jó-

8 Belső idézet: Kazinczy Ferenc: Dayka élete. Kazinczy: Válogatott művei II., 171. 
zsef szintén második kötetét magyar-ugor összehasonlító szótárának. [...] Ily munkálkodás képes lesz a nyugaton, még tudós körökben is, megrögzött annyi tévedést, fajunk nyelvünk, $s$ az egész altáiság irányában, helyre igazitani: s a világhódító árja gögöt, mely nyelvünket épen formagazdagságáért, a fejletlenebbek, - fajunkat a fejlödésre nem is képesek közé sorolja, mérsékeltebb véleményre hangolni" (AJÖM XIV: 530). [Kiemelés: T. I.]

\section{Népköltészet és irodalmi nyelv}

A nyelvújítás korát és hatástörténetét vizsgáló írásokban elsősorban a szépirodalmi és nyelvészeti szempontok érvényesülnek. Természetesen mindkét regiszterben figyelem irányul az idegen nyelvből magyarra fordítás elvi, elméleti vitáira is. A fordításokkal kapcsolatos elméleti megfontolásokat a megszokott irányvonalaktól eltérően kívánom megvizsgálni. A fordításról szóló diskurzusok legalább két fontos szálon futottak a 19. század folyamán: az idegen domesztikációjának, azaz az idegen nyelvü irodalom magyar tolmácsolásának és a saját, a paraszti, népi nyelvhasználat, a népköltészet interpretálásának a mikéntjéről szóltak. Az utóbbi esetében arról folytak viták, hogyan használható fel az elit irodalom számára a nép ajkáról gyűjtött költészet és tágabb értelemben a népnyelv. A többek között Kölcsey által képviselt vélemény szerint a népi/ népies stílust kell megfelelően átültetni a modern irodalomba, míg mások, például Bajza József, maguknak a népi alkotásoknak a „felemelését” szorgalmazták.

Az idegenből érkező irodalom tolmácsolása a magyar közönség számára pezsgö fordításelméleti vitát indított útjára, és a külföldi népköltészeti alkotások fordításában mindkét felvázolt kérdéskör (hazai, népi, tájnyelvi sajátságok felhasználásának és az idegen nyelv megfelelő lefordításának problémája) kumulálódott. Erre utalnak Eisemann György sorai, amelyek szerint „,a romantika formatudata számára a népies hang idegen hangot jelentett: megszólalásának mássága egy addig ismeretlen múltat, vagyis egy újonnan fölismert anyanyelvi szubkultúrát, mint historikus előzményt aktualizált" (Eisemann 2014: 104).

Érthető, hogy a vizsgált korszakban mennyire elválaszthatatlan volt a fordítás normáinak felállítása a magyar nyelv standardjának (az egységesítendő köznyelv és irodalmi nyelv) kialakításától. Az utóbbi folyamatban pedig két különösen fontos vezérvonal fogalmazódott meg a 19. század közepére. Az egyik a magyar nyelv tisztasága körüli diskurzus, amelynek fő gondolatai arról szóltak, hogy az idegen nyelvi hatásokat, latinizmusokat, de még inkább a germanizmusokat minimálisra kell csökkenteni. Brassai Sámuel számos esszéjét szentelte ennek a kérdésnek, és a nyelvújítási alkotásokat is súlyos bírálattal illette. A nyelvhelyességgel kapcsolatos élénk vitáknak köszönhetően születtek olyan művek a 19. század második felében, mint például Szarvas Gábor Magyartalanságok című értekezése (1867), illetve Simonyi Zsigmond A magyar nyelvújításról címet viselö, a reformkori törekvésekre immár több évtizednyi távolságból visszatekintő értékelése (1875). Ezek a müvek egyre szélesebb körben irányították a hibátlan magyar nyelvhasználat kérdésére a figyelmet. A másik fontos vezérvonal tulajdonképpen az előzőnek a leágazása, hiszen a magyar nyelv mesterkéltségtől, idegenszerűségtől való megtisztításához az ideális 
mintát a népnyelv, ezáltal a nép költészete szolgáltatta. Többek között ezt az elvet valósította meg Arany költészete:

„Ez alaptehetséghez Aranynál még különböző körülmények járultak nyelvének fejlesztésére és öregbítésére. A nép közt nevelkedett, a nép közt töltötte el élete legjavát. Ez az érintkezés meglátszik mindenekfelett költeményei nyelvén, mely tele van népies szólamokkal és népies szókötési fordulatokkal. A mit még le nem írtak soha, a mi könyvben még elő nem fordult, azt nagy merészséggel és nagy ízléssel beviszi a magas szárnyalású költészetbe. A népiesség - Arany nyelvének ezen szembeszökő sajátossága - minden irányban mutatkozik nála: a népies nyelv egyes hangtani sajátságaival ép úgy él, mint bizonyos alaktani formáival; irodalmilag még el nem koptatott szókincsét ép annyira tudja értékesíteni, mint fordulatait és mondatszerkezetét" (Riedl 1887: 260).

A népnyelv és az irodalmi nyelv körül formálódó, azok eszményi elegyítésére vonatkozó elméleti diskurzusokban azonban komoly feszültség, sőt ellentmondás feszült, ahogyan arra Tolcsvai Nagy Gábor is felhívja a figyelmet. A 19. század közepére, tehát pont Arany szerkesztői tevékenységének az idejére a kodifikált standard irodalmi nyelv „,komoly tekintélyt szerzett a népnyelvvel szemben, amit csak részben ellensúlyozott az irodalmi népiesség, illetve a nyelvjárások, a népnyelv továbbra is »tiszta forrásként« értelmezése" (Tolcsvai Nagy 2010: 17). Ez a feloldhatatlan kettősség tükröződik a Szépirodalmi Figyelö és a Koszorú számos írásában, amelyek a népköltészet és az elit irodalom összehasonlításának, összehangolásának a kérdésére irányultak. A problémának többek között Szász Károly és Arany is határozottan adott hangot több írásában, példaként álljon itt mindkettőjüktől egy-egy idézet:

„minden nép, faji, állami, vallásos, társadalmi sajátságai - egyénisége szerint gondolkodik, érez költ: s mig miveltsége (tehát müköltészete) az idegenekével közös vívmányokat szintén magába veszi, - népies gondolkodási s érzési módja, - tehát népköltészete - is, jobban megörzi népegyéni sajátságait, és ezáltal az idegenre az újdonság, a különösség ingerével hat..." (Szász, SzF 1861/42: 660).

„Oly korban, midőn nyelvünket a fejlődés nevezetes fokára jutottnak véljük, egy egészben hét századra fölvihetö irodalom s közel egy század óta (a testőröktől számítva) folyó irodalmi reform után ott vagyunk, hogy legjobb íróinkban hiába keressük az igeidők használásának törvényeit, hogy nyelvészeink csak most vesződnek e törvények feltalálásával, ellenkező, egymást lerontó theoriákat állitnak fel; a népnyelv pedig sem egyiket sem másikat el nem ismeri. Ha az irodalmi nyelv történetét kérdezzük, ez a legrégibb hajdaniul mintegy a múlt század derekáig oly állandó törvénvt mutat fel, melynek lehetlen volna nem hódolnunk, ha a népnyelvben, a mai élö nyelvérzékben elegendő támaszát lelnök, s igy a latinosság vádjától megtisztithatnók. [...] En nem tudom a magyar igeidők helyes használatát. Hiszen megírta Hunfalvy, Fogarassy. Irja most is Brassai stb. Még ugy se’ tudom. Egyik 6-7 százados irodalmi gyakorlatra utal, másik a franczia időknek megfelelő árnyalatokat keres és talál nyelvünkben, még a harmadik a népre, az élő nyelvre hivatkozik. Homlokegyenest ellenkező theoriák tülkölödznek egymással” (Arany, SzF 1861/I., 41: 641-2). 
A két irodalmi terep metaforáiként sokszor a „közeli” és a „távoli”, a „földi” és az „égi” szolgáltak, utalva a nép költészetének „egyszerü” és a hétköznapi életből vett tárgyaira, szemben a müköltészet ettöl eltávolító, magasztos témáival. Ennek egyik jellemző kritikáját olvashatjuk a következő idézetben: „Ballada-irónk, tiz közül kilenc esetben, megolvas a históriából egy nevezetes tényt: ez s amaz hős mikép vette be a várat, hogyan vágta le ellenségét, mily vitézül esett el, kevesed magával roppant tulerő által elboritva. stb. gondolja ez neki jó tárgy" (SzF 1861/22: 343). A hétköznapi tematika és a népi költői eszközök piedesztálra emelése, a naiv pátosz megtalálása, az egymástól távolra szakadt költői világok közelítésének az igénye egyre határozottabban fogalmazódott meg a 19. századi irodalmi lapokban, így Aranynál is. Ennek a szemléletnek köszönhetően került rögtön középpontba (és kanonizálásra) Petőfi költészete, valamint figyeltek fel olyan külföldi szerzőkre, mint a paraszti származású Robert Burns, aki költészetében ideálisan vegyítette a tájnyelvi sajátosságokat, a helyi, népi témákat a magas irodalmi stílussal. Ezzel szoros összefüggésben fogalmazódott meg a tehetség 19. századi definíciója: a közös, nemzeti (értsd: népi) eszköz- és tudástárat mesteri módon felhasználó, nem pedig egyéni témákat és stílust alkalmazó alkotó, aki a külhoni mintákkal szemben az anyanyelvi forrásból merít. Mindez jelentős szemléletbeli eltávolodás Kazinczytól és körétől. A Shakespeare müveinek lefordítását megelőző és kísérő elméleti viták kapcsán magával Shakespeare-rel kapcsolatban is többször megfogalmazódott, hogy nagysága éppen abban állt, hogy „,saját korával és nemzetével egygyé vált szív és lélek”, azaz eredetiségének és tehetségének „lényege nem a másoktól való különbözés, hanem inventív viszonyulás ahhoz, amit a költő másoktól kap, vagy kaphat" (Török 2005: 31). Shakespeare népszerüsége részben annak volt köszönhető, hogy kreatívan élt a hagyomány által „,készen szállított” anyaggal, müveiben felhasználta a szóbeliségből is ismert elemeket. Fontos ugyanakkor látni azt is, hogy itt nem egyirányú folyamatról volt szó, hanem az oda-vissza hatás folytonos és megtermékenyítő dinamikájáról. Az írni-olvasni tudás széles körü elterjedése előtt is számos esetben megfigyelhető az elit irodalom hatásának a megjelenése a népköltészetben. 19. századi és hazai példánál maradva, elég Petöfi költészetének népköltészeti interpretációira, folklórrá válására gondolnunk. Míg az irodalom a saját, nemzeti hangjának a megtalálásához a népi, ,romlatlan” (értsd a korszakban sokat kritizált latinizmusoktól és germanizmusoktól mentes) népköltészetben látta az igazi forrást, utóbbi is azokat a hatásokat fogadta be elsősorban, amelyeket legkevésbé érzett idegennek. Az ismerős hatást keltő, más területekről érkező folklór és az elit irodalom egyes alkotásai egyaránt megtermékenyítően hatottak, utóbbiak folklorizálódhattak, azaz válhattak variánsokban létező és a szóbeliségben továbbhagyományozódó szövegekké. Tehát vertikálisan és horizontálisan is megfigyelhető volt az alkotások ,vándorlása”, formálódása.

A Szépirodalmi Figyelóben azt olvashatjuk, hogy „A költőnek nemzeti hagyományokat kell készen birnia; ezekre épit, s viszont, müvészetének ezek szolgálnak mértékül" (SzF 1862/II., 2: 66). A herderi álláspontot továbbörökítve a 19. századi irodalmárok a müköltészet megújulásának forrását és feltételét tehát a népköltészetben látták (Ruttkay 2016: 24). Továbbá:

„Az idealizált, gyengéd Burns fontos nemzetközi mintaként szolgálhatott ebben a konstrukcióban [...] 1870-ben Szana Tamás (a Petőfi Társaság titkára) Burnst »csu- 
pán népköltő«-ként írja le, »de a szó legnemesebb és legtisztább értelmében«: »A müés népdal közti különbség nála alig érezhető s éppoly kevéssé kacérkodik a bölcsészi gondolatmélységgel, mint az erőszakolt naivsággal és népiességgel, mely könnyen válhatik köznapivá és póriassá.« [...] Gyulai Pál szerint például »a legsikerültebb balladákat s balladaféléket azon költők írják, kik főleg a népköltészet hagyományain növekednek, igy az angolok között Burns, a francziák közt Béranger, a németek közt Goethe és Uhland, közöttünk Arany«" (Ruttkay 2016: 22).

A népiességtematika tehát bekapcsolódott egy tágabb, nemzetközi diskurzusba is. A nagyszabású Goethe, Shakespeare, Burns stb. fordítási projektek célja a nemzeti nyelv formálása, fejlesztése mellett a népmüvelés volt. Az irodalmi lapok voltak a szócsövei a külföldi irodalmaknak és a (részben szintén külhoni és természetesen a magyar) népköltészetnek, és mindez nemcsak puszta szövegfordítások révén valósult meg, hanem a művek történeti, társadalmi és kulturális kontextusának a bemutatásával is. Az idegenből érkező irodalom ismerőssé tételének, a kulturális fordíthatóságot és a célközönség befogadását könnyítő értelmezések bemutatásának ekkoriban is megvolt már a maga tágabb kontextusa, irodalmi előzménye. Jól tükrözi ezt a 19. század közepétől keletkezett idegen nyelv tanítását/tanulását szolgáló nyelvkönyvek felépítése. A nyelvtanulás ugyanis részben irodalmi szövegek olvasása és fordítása réven történt, emellett az ismeretszerzés kötelezően kiterjedt az adott ország kultúrájára is. Ennek eszmetörténeti hátterében megemlíthető például a híres német nyelvész, Wilhelm von Humboldt azon véleménye, miszerint az adott nyelv és az adott kultúra ismerete egymást feltételezik.

A 19. század második felére tehát a nyelv és az „országismeret” oktatása erősen összekapcsolódott, a nyelvkönyvek az irodalmi szövegpéldákon túl etnográfiai, földrajzi és történelmi adalékokat közöltek a célnyelv beszélőiről (Pelcz 2006: 97). Arra is találunk példát, hogy folklórszövegre épült egy nyelvkönyv, mint például Josef Holtzmann németek számára készült, a magyar nyelv tanulására szolgáló segédlete, amely Gyulai Pál meseszövegét dolgozta fel folytatásokban (Máté 2009: 49-57). De megemlíthetjük a rokon nyelvek korabeli kutatását is, hiszen a kisebb finnugor nyelvek megismerése nagyrészt a népköltészeti gyüjtésekre épült. Ha csak Reguly és Munkácsi obi-ugor gyüjtéseit vesszük alapul, hazahozott nyelvi mutatványaik jelentős része folklórszöveg volt. Ezekre a mủvekre különösen nagy figyelem irányult, hiszen bennük a nyelvrokonság (és részben néprokonság) bizonyítékait vagy éppen ellenérveit keresték, látták.

Visszatérve a külföldi mü- és népköltészet magyar tolmácsolásához, szót kell ejteni a korabeli szövegközlési gyakorlatról, amely szintén összefügg a nyelvújítás egyik fö törekvésével, a megfelelő és korszerü magyar szókincs megteremtésével (a stílusrétegekre is odafigyelve). Bár a hitelesség, a szöveghüség fontossága már előfordul több szerzőnél, például Lévaynál a skót balladák közreadása, Aranynál egyes Burns-fordítások kapcsán, a magyarra fordított szövegekben mégis inkább az esztétikai szempontok és az értetőség elvei dominálnak, azaz a célközönség számára lehetségessé tenni a szöveg lehető legteljesebb befogadását. A szöveghüségről és a nyelvi-formai minőségről szóló diskurzust jól szemléltetik azok a (részben pejoratív) szinonimák (lásd mindkét idézet kiemelt részeit) és kritikus, ironikus meg- 
szólalások (mint a második, Brassaitól származó idézet), amelyeket a fordításokra vonatkozóan használtak a Szépirodalmi Figyelő hasábjain:

„Burns Robert néhány utánzása (fordítás) is van e gyüjteményben, mely megérdemli, hogy felé forduljon a közfigyelem" (SzF 1861/22: 422).

\begin{abstract}
„Hiszen időszaki sajtónk forgó tökéjében alig van egy divatosabb rovatszám, mint im e kifejezés: »műfordítás«. Megjelen egy vagy más lapban vagy havi füzetben egy átnyelvitett beszélyke vagy költeményke, és ha más nem, az illető szerkesztő azonnal reá süti a müfordítás bélyegét. A sütés alatt ugyan a forditó helyett a criticus olvasó hunyorog nem egyszer; de gyakori és biztos használata mégis csak arra mutat, hogy mi már egészen tisztában volnánk a fordítás fogalmával elméletileg és gyakorlatilag" (Brassai, SzF 1861/19: 289).
\end{abstract}

A Szépirodalmi Figyelö és a Koszorú is nagyon tág teret adott a fordítási kérdésekről szóló vitáknak. A Figyelő egymást követő öt lapszáma Mégis valami a fordításról címmel Brassai szigorú véleményét mutatta be nemcsak a fordítás, hanem a nyelvújítás kérdéskörben is, amelyekre szintén öt terjedelmes részletben közölte a folyóirat Arany reflexióit Visszatekintés címmel. Ezek az írások legalább annyira szólnak a műfordítás problematikájáról, mint a magyar nyelv normarendszerének kérdéseiről, a tájnyelvi szavak köznyelvivé/irodalmivá tételétől a grammatikai kérdéseken át az ortográfia problematikájáig. Kazinczy nyelvújátásának ${ }^{9}$ is hat számban szentelt Arany központi helyet, és a fent említett írások mindegyike „vezércikk”ként jelent meg a Figyelóben. Ez is jól mutatja, hogy Arany Jánost nem csupán irodalmárnak, hanem a korszak központi jelentőségü irodalom- és nyelvtudósának is kell tartanunk. Korántsem volt tisztázott tehát, hogy mit és hogyan lehet müfordítás címén közreadni, hosszú tudományos és irodalmi vita előzte meg például a Shakespeare müvek lefordítását. A későbbiekben látni fogjuk, hogy bizonyos témák (nemcsak a lehetséges politikai cenzúra miatt) kerülendők voltak, aminek az okát Brassai megfogalmazásában tolmácsolhatjuk: „Fordításoknak nálunk az izlés fejtésire és nemesitésire kell szolgálni” (Brassai, SzF 1861/19: 290). „Legyen a fordítás nemzeties!" - folytatva Brassai gondolatait:

„Mellőzve minden más epithetumokat, mint müvészi, szolgai, szabad, remek vagy legényi, még napszámosi is, azt hiszem, vitatlan lényeges vonás gyanánt állithatjuk fel az eredetihez való hüséget [...] Határozzuk meg hát: melyek azok az országlási pontok, mikre nézve teljes hűséggel tartozik a forditó az ö fejedelmének, az eredeti münek. Én csak kettőt birok lelni: a gondolatot és a stílt, ez elválhatlan ikerpárt. [...] Következőleg ha az eredeti irónak a gondolatját rajzban és színezetben a forditó átadja a maga nemzetének, evvel a fordítói hüségnek tökélyesen eleget tett" (SzF 1861/27: 418-9).

„egyetlen kötelessége a forditónak, magyarul, nemzetiesen magyarul írni. Más szóval: a fordítás olyan legyen, mintha a szerző az ö egész egyéniségivel, képzelödésivel

9 Ebben a sorozatban is az egyik írás kifejezetten a fordítás problematikájával foglalkozik Kazinczy mint müforditó címmel (Imre, SzF 1861/8: 113-9). 
és eszével tiszta magyar és magyarul beszélő családban nevekedve, magyarul irta volna az illető munkát, ugy magyarul, hogy azon semmi idegen iz se érezzék" (SzF 1861/28: 433). [Kiemelés: T. I.]

A „,nemzeties” fordítás szükségességét azért (is) emelte ki ennyire Brassai, mert szerinte a magyartól idegen nyelvi elemek pont a fordításoknak (így a „müirodalomnak") köszönhetően gyökeresedtek meg (pl. SzF 1861/30: 465; SzF 1862/II. 9: 130). A nyelvrontásban a nyelvészek és a fordítók felelősségét hangsúlyozta, megerősítve azt a korabeli köteléket, amely a magyar nemzeti nyelv ürügyén a nyelvészetet és az irodalmat egybefüzte. A korabeli gondolkodásban tehát a fordításoknak fontos felelőssége volt a nemzeti nyelv erősítésében vagy gyengítésében. Gyulai Pál Brassaival ellenkező nézeteket vallva így nyilatkozott erről a kérdésről: „A fordításnak és átdolgozásnak elvi ellenzése nemcsak müveltségünknek ártana, hanem ártana nemzetiségünknek is, mert a fordítás a nemzetiségi eszme kifolyása, s gyengítése az idegen nyelv beolvasztó erejének" (Gyulai 2008: 243).

Az irodalmi nyelv fejlesztésének két fö útja ebben az időszakban tehát a külföldi és a saját népi irodalom megfelelő módon történő „,beemelése” - a nemzeti irodalmi nyelvre átültetése - volt. A mikéntről azonban élénk viták folytak, és a fordítás metaforája a saját népköltészeti szövegek esetében is relevánssá vált. A szövegközlési gyakorlatra vonatkozó fontos, kifejezetten a népköltési szövegek kiadását érintő problémára világított rá Lévay Józsefnek a skót balladákat bemutató írása (SzF 1862/II. 1: 1-4; 1862/II. 2: 17-20; 1862/II. 3: 33-6). Érdekes módon Lévay erősen bírálta a 18. századi szöveggondozási és kiadási eljárást, jóllehet annak számos vonása, például a szövegek átírásának, kiegészítésének vagy éppen rövidítésének gyakorlata átörökítődött a 19. századra, és a szerzői jog, a honoráriumok szabályozása, ezzel együtt az eredetiség elvi szabályozása még kiforratlan volt (Voigt 2010: 152). A folklórszövegek esztétikai alapon történő válogatása, a gyüjtő, kiadó publikálás előtti javítása és átdolgozása általános eljárás volt a 19. század közepén, és még azt követően is hosszú ideig. ${ }^{10}$ Ennek a szemléletmódnak a következményeképpen csak hozzávetőleges elképzeléseink lehetnek arról, hogyan hangzott élőszóban egy-egy folklórszöveg, mielött a levelezés útján kiterjedt gyüjtőhálózat önkéntesei és felkért résztvevői papírra vetették volna őket. Ezek után pedig általában a kiadók is eszközöltek változtatásokat. Ezért is előremutatóak azok a gondolatok, amelyekben Lévay nagyító alá veszi az előző század (jelen esetben) skót balladagyüjteményeinek hiányosságait:

„A skót nemzeti költészet régi maradványait már egy századdal ez elött kezdé gyüjtögetni Allan Ramsay. - Költői érdeme elvitázhatlan; de gyüjtői s kiadói kötelességét nem ugy fogta fel s nem ugy teljesité, mint az ügyre nézve kívánatos vala. - Kényekedve s a divatozó izlés szerint módositgatta, szinezgette, változtatta a hozzá került ó-anyagot, - mi által nemcsak rosz példát nyujta, de fölötte megnehezité az utódok eljárását is, kik e költői emlékek összegyüjtésében minden áron a tiszta eredetinek fölismerésére törekedtek" (SzF 1862/II. 1: 2). [Kiemelés: T. I.]

${ }^{10}$ Még a 20. századi népmesekiadás során is megfigyelhető az eufemizáló szövegalakítás, illetve a közízlést, jó modort túlságosan sértő részletek elhagyása (Milbacher 2000; Gulyás 2010). 
A recenziót tovább olvasva persze kiderül, hogy az adott anyagtól nagyon eltérö tárgy és nyelvi stílus alkalmazásában látott inkább kivetnivalót, mintsem az esztétikai megfontolásokban általában. Jól bizonyítja ezt, ha egyik Burns fordítását ${ }^{11}$ öszszevetjük az eredeti szöveggel, amelyből bizonyos részeket egyértelműen elhagyott. Mégpedig a közízlést sértő sorokat, hiszen a publikációknak erkölcsi és morális követelményeknek kellett megfelelniük. ${ }^{12}$

A folklorisztika tudománytörténetében evidenciaként szerepel a folklórszövegek esztétikai alapon történő válogatásának a gyakorlata és a szó szerinti megjelentetés helyett az átírt, megvágott, kiegészített változatok közlése (lásd pl. Gulyás 2011a, 2011b, 2015), annak ellenére, hogy a század közepére már a népköltészet kifejezésmódját eszményítő vélemények fogalmazódtak meg. Ilyen például a $V a$ sárnapi Ujság szerzőjétől származó idézet: „A beszéd olly kifejlett, jó hangzatu s értelmü minden egyes pór szájában, hogy beszédét csekély változtatással azonnal utána lehet nyomatni; a czikornyás, keresett, s érthetőséget zavaró kifejezés inkább a főbb rendüek sajátja" (Dr. F, VU 1854/12: 96).

Fontos azonban annak tudatosítása, hogy a hitelesség a 19. században a magyar nemzeti nyelv megfelelő használatára és nem az eredeti változathoz való betü szerinti ragaszkodásra vonatkozott. A népköltési szövegek ,idealizált” közlésében a központi megfontolások számos ellentmondást hordoztak magukban. Egyszerre próbálták megvalósítani az esztétizálást és a szöveghűséget. Utóbbi ebben az időszakban nagyon is folklórjellegü szemléletmódot tükrözött, azaz egy feltételezett eredeti, egyetlen változattal szemben a szövegek szabad alakíthatóságát. A publikált szöveg a müvelt és erkölcsös olvasóközönség ízlésének, illetve a népnevelö szándéknak is alárendelödött. A magyar standard nyelvhasználat felé mutató megformálás szándéka és a népi-táji jellegzetességek bemutatása egyaránt jellemzi a szövegkiadásokat, miként az illetlennek ítélt tartalmak kiiktatása vagy átfogalmazása, esetenként saját ötletek alapján történt kiegészítése is. A tudománytörténeti áttekintésekben ez a kiadói eljárás - tudomásom szerint - sosem került közvetlen összefüggésbe a külföldi műalkotásokkal kapcsolatos gyakorlattal, kizárólag a népköltészet alkotásainak közlési módjával. Ebben a leszükített megközelítésben az értelmezés könnyen billenhet abba az irányba, hogy a szájhagyományból gyüjthető népköltési szövegeket „egy az egyben" nem tartották eléggé jónak, irodalmilag fogyaszthatónak és a magyar nemzeti karaktert „,nyers” formájukban, javítások nélkül is „,fogyaszthatónak” és a nemzeti nyelv emblematikus megjelenítésére képes alkotásoknak. A folklóralkotásokat a szigorú kritikusok általában nem a nyelvi megformálás szempontjából bírálták, sőt érzékelhető az a tendencia, hogy a standardtól eltérő, egy-egy „népinek” érzékelt kiejtési formát az írásmód révén is igyekeztek megmutatni, például: „odamegyek, csillagom, hát látom, hogy ú feje be van törve” (Arany, SzF 1891/41: 643) vagy „A nyúl is megijjed, s mind a hárman együtt / A mint igy szaladnak, kérdi tölök az öz..." (SzF 1891/ 40: 632). [Kiemelés: T. I.]. Legfőbb kifogásaik tehát tartalmi jellegüek voltak. Vagy a témát nem találták kellően magasztosnak vagy kifinomultnak, vagy a vaskos, esetleg obszcén részeket nem tartották méltónak arra, hogy nyomdafesté-

${ }^{11}$ A vers Arany fordításában jelent meg kihagyás nélkül, Kóbor Tamás címmel.

12 Többek között azért is, mert követendőnek tekintették azt a skót, svéd és finn példát, miszerint az iskolai tananyagba be kell vonni a népköltészeti alkotások oktatását is. 
ket láthassanak. Ha figyelembe vesszük, hogy nemcsak a folklór-, hanem az egyedi szerzőséghez kötődő, külföldi müalkotásokkal is hasonlóképpen jártak el, teljesen más megvilágításba helyeződik a korabeli gyakorlat. Az irodalmi publikációknak ugyanis (legyen szó népköltészetről vagy külföldi müköltészetről) fő rendeltetése a standard magyar nyelv kialakítása és a közönség nyelvhasználatának jobbítása volt. Tehát nem a szöveghüség, hanem a szöveg értelmét és müvészi megformáltságát közvetítő esztétizáló igény jelentette a központi célkitüzést mind a folklórszövegek közlése, mind az idegen nyelvű szövegek (szépirodalom, folklór) fordításai esetében. A Figyelóben és a Koszorúban Kazinczyval szemben megfogalmazódó kritikák is e kérdések körül oszcillálnak. Gyulai Pál Vörösmarty nyelvéröl címet viselő értekezésében tulajdonképpen minden lényeges kritikai adat megjelenik, amelyek általában előkerültek a Figyelő és a Koszorú hasábjain: ${ }^{13}$

\begin{abstract}
„Kazinczyt tartják a magyar ujabb költői nyelv megalapítójának, s ez igaz is, ha átalános szempontból ítélünk; de tisztán nemzetiből Vörösmartyt illeti e dicsőség. Nem tagadhatni, hogy Kazinczy nélkül bajosan állhatott volna elö Vörösmarty, de az még bizonyosabb, hogy Kazinczy iránya a mily jótékonyan hatott egy ideig, épen olyan kártékonyán hatott volna később, ha Vörösmarty a jól-roszul müvészivé emelt költői nyelvet át nem változtatja egyszersmind magyarrá is, azaz nemzetileg müvészivé. Kazinczy zagyva ellapult prózánkat, köznapi és emelkedés nélküli költői nyelvünket igyekezett kiemelni sülyedtségéböl. A nyelv aesthetikai oldalát mivelte, annyira, hogy nyelvújitása is innen indult ki, s a nyelvtani szempontot minden habozás nélkül feláldozta az aesthetikainak. Tudta, hogy a költöi nyelv nem a köznapi beszédnek rimbe vagy mértékbe szedése, hogy minden költői nemnek, fajnak megvan a maga stylja, s a báj nagy része a szók és kifejezések árnyalati gazdagságától s a szókötés egy csoport fordulata- és alakzatától függ, melyek épen ugy befolynak a költői gondolat kiemelésére, mint a rhythmus hangzatosságára. Idejárult még, hogy költészetünkben a klasszikái és európai modern versformák kezdettek miveltetni. [...] Kazinczy nem annyira a magyar nyelv természetéből igyekezett kifejteni költői nyelvünket, mint inkább idegen nyelvek kifejtett költői szépségeit ültette át a magyarba. Ugy óhajtott szólni magyarul, mint a régi s ujabb klasszikusok, s ez helyes volt, de abban tévedt, midőn azt hitte, hogy ezt latinismus és germanismus által is eszközölhetni. [...] Kazinczy izlést és formai érzéket költött fel költőinkben, de mesterkedést is; elválasztotta a költői nyelvet a köznapitól, de nem egy tekintetben a múvészit is a magyarostól” (K III/23: 545-9).
\end{abstract}

Imre Sándor kifejezetten bölcsen és lényeglátóan helyezte el Kazinczy szerepét a magyar nyelv alakításának, központosításának a folyamatában, a kritikai élt azzal tompítva, hogy nem lehet retrospektíve ugyanazt számon kérni a nagy nyelvújítótól, amit a későbbi korok nyelvművelöitől és szerzőitől:

„Kazinczy jeles költő volt, ha korának íróira, költöire tett hatását veszszük számba: de nem nagy, ha e nevet csak olyakra kívánjuk ruházni, kik egy nemzet életére voltak közvetlen vezetői hatással. Népszerü nem lehetett, verseit a nép nem énekli, - ilyen lenni nem is vágyott, mint Goethe sem. Természetes volt, hogy a müizlés- és nyelvújí-

${ }^{13}$ Természetesen egyes szerzőknél a pró vagy kontra érvek felé tevődik át a súlypont, utóbbi kifejezetten jellemző Brassai megnyilvánulásaira, a legtöbbször azonban egyszerre találkozunk a méltatás és a jószándékú kritika harmonikus együttállásával, amely minden bizonynyal Arany szerkesztői tevékenységének is köszönhető. 
tás felülröl a nemzet müvelt osztályainál kezdödjék, ezekben támadjon fel a régi iránti ellenszenv és az újnak óhajtása. Ez volt az ö feladata, s ezt maga is érezte; a többi, a megújult eszmék, nyelv- és költői alakok elterjedése a nép körében, a költészet megújulása népies alakok által, a népszerü költészet feljutása, az új classicai iskola alapítójának gondolatában sem lehetett" (K I/10: 220).

Imre Sándor abban is egyetértett Kazinczy törekvéseivel, hogy elöször az ízlésre kellett hatni, azt kifinomultabbá tenni, azaz az újítások befogadásához megteremteni a kellő táptalajt: az igényességet: „Tehát a nemzetet kellett először felvonszolni a müvelt izlés magasságába, s megihletni egész valóját, hogy csekélységnek tekintse a régit, hogy multja egész kifejezését feláldozza a jelen kor szükségének" (84). Ugyanakkor ennek nehézségeivel, esetenként káros hatásával is számol: „Mert minden kifejezésben a nemzet valamely eszméje foglaltatik, minden kifejezésmódban annak lelke él és mozog; a nemzet a nyelvben él. Ha ezek módosíttatnak, a nemzet szellemét érinti a romboló kéz." Ehhez kapcsolható az a gyakorlat is, hogy a grammatikát érintő kérdésekben számos szerző tekintette kiindulásának a népnyelvet, szemben az idegen nyelvi minták honosítására való törekvéssel. Jól illusztrálja ezt a vizsgált két folyóirat számos nyelvhelyességről szóló vitája is, miként a következö, Arany János tollából származó, a múlt helyes kifejezéséről szóló okfejtésben is olvasható:

„A mit én a multak s átalában az idők használatára nézve, Bihartól Pestig, tapasztaltam, az leginkáb összevág Imre Sándor észrevételivel, melyeket pár éve, talán a Magyar Nyelvészet lapjain, elöadott. A nép, mennyiben én ismerem, a t-vel ragasztott multat használja legtöbb esetben, ha beszéde elmúlt idöre vonatkozik, legyen az imperfectum, aoristus és perfectum, vagy plusquamperfectum viszonyban [...] Mellözve a múltnak jelenitését, midőn t. i. az elbeszélö nép is, szintugy mint az iró jelenidöt használ ..." (Arany SzF 1891/41: 643). [Kiemelés: T. I.].

\section{5. Összegzés}

Tanulmányomban a nemzeti nyelv, a nyelvújítás, a nyelvrokonság, a népköltészet és a fordítás tematikájának 19. századi szoros összefonódását kívántam szemléltetni reflexiókkal a nyelvújításra és annak értékelésére. A vizsgált korszakban a különböző diszciplínák egyértelmü elválásáról még nem beszélhetünk, és az alkotók személyében is megfigyelhető a többes tematika erőteljes „,együttállása” (a nyelvtörténeti, esztétikai és nemzeti szempontok polifóniája). Ugyanazok az irodalomban is tevékeny emberek dolgoztak a folklórszövegekkel, akik a nyelv megreformálásáról és a müfordításokról szóló diskurzust alakították. Brassai számos alkalommal a nyelvészek és a fordítók (írók) közös felelősségét hangsúlyozta. A rokon nyelvek megismerésére irányuló nyelvészeti gyüjtések valójában folklórgyüjtések is voltak. A nyelvrokonság paradigmájának kidolgozása jelentős mértékben épült a Reguly, Munkácsi és mások által gyüjtött népköltési szövegekre. Az idegen nyelvü folklór és müköltészet küldetése az irodalmi érték felmutatásán és megismertetésén túl kulturális és etnográfiai adatok közvetítése volt, továbbá a „néplélek” illusztrálása, amely erősen kapcsolódott a népek rokonságának a kérdéséhez is. 
A fordítások válogatása mintaként szolgált a nemzeti irodalomhoz. A figyelem (a különböző népek folklórszövegei mellett) olyan szerzőkre irányult, mint Shakespeare, Burns, Goethe, akik példaként szolgáltak a népies nyelvezet és stílus, valamint a müköltészet ideális összekötéséhez, a közösségi müfajok és az egyéni szerzőség, kreativitás idealizált viszonyához. A korabeli fordítások létrehozói általában éltek mind az esztétikai és etikai cenzúra, mind a szabad szövegalakítás gyakorlatával. Ezzel öszszefüggésben megállapítható, hogy a népköltészeti szövegek válogatása, az adott korszak irodalmi ízléséhez igazítása, a köznevelést célzó igényeknek való megfeleltetése, valamint a szövegek szabad átírási gyakorlata egy jóval tágabb, a müfordításokat is jellemző - részben klasszicista, részben nemzeti - diskurzusba illeszkedett. Ebben a folyamatban tehát természetszerüen megnyilvánult a nyelvmüvelés praxisának mindkét iránya, a neológia és ortológia is, a vizsgált források pedig Bodrogi Ferenc Máté szavait kölcsönözve a „tudatos nyelvhasználat-irányítás szimbolikus dokumentumai”, a cél pedig ,a magyar nyelv mint egész elismertetése volt” (Bodrogi 2005: 70, 85).

\section{SZAKIRODALOM}

\section{RÖVIDÍTÉSEK}

AJÖM XIV. 1974. = Arany János Összes Müvei XIV. Hivatali iratok 2. Akadémiai évek.

Szerk.: Keresztury Dezső, sajtó alá endezte: Gergely Pál. Akadémiai Kiadó, Budapest.

$\mathrm{K}=$ Koszorú.

KFL III. = Kazinczy Ferenc Levelezése. III. kötet. 1803-1805. Sajtó alá rendezte: Váczy

János. Magyar Tudományos Akadémia, Budapest

$\mathrm{SzF}=$ Szépirodalmi Figyelö.

Arany János (A. J.) 1861. Visszatekintés. I. Szépirodalmi Figyelö 36: 561-7.

Arany János (A. J.) 1861. Visszatekintés. II. Szépirodalmi Figyelő 37: 577-80.

Arany János (A. J.) 1861. Visszatekintés. II. Szépirodalmi Figyelö 38: 593-6.

Arany János (A. J.) 1861. Visszatekintés. VI. Szépirodalmi Figyelö 38: 641-5.

Arany János (A. J.) 1865. A vajon kérdéséhez. Koszorú 1865/I: 571-2.

Arany János 2003. Arany János összes költeményei I. Versek, versforditások és elbeszélő költemények. Sajtó alá rendezte és jegyzetek: Szilágyi Márton. Osiris, Budapest.

Bodrogi Ferenc Máté 2005. „Forrni kell a bornak, ha valaha tiszta akar lenni” Nyelvművelés volt-e a „nyelv mívelése” a nyelvújítás korában? Magyar nyelvjárások XLIII: 69-94.

Brassai Sámuel 1861. Még is valami a fordításról. I., Szépirodalmi Figyelő 19: 289-91.

Brassai Sámuel 1861. Mégis valami a fordításról II. Szépirodalmi Figyelő 28: 431-6.

Brassai Sámuel 1862. Nyelv és nyelvészet. Szépirodalmi Figyelö 9: 129-31.

Dr. F 1954. Vasárnapi Ujság 12: 96. https://www.scielo.br/scielo.php?script=sci_ arttext\&pid=S0004-282X1954000200002

Eisemann György 2014. Az idegenség elsajátítása - a saját idegensége (Identitás és individualitás feszültsége a romantikus és modern lírában) Mühely 37/5-6, 103-7.

Gulyás Judit 2010. Szövegalakítási eljárások a népmesekiadás során. A „Rózsa elfelejti Ibo- 
lyát" mesetípus nagyszalontai kéziratos és kiadott variánsai. In: Szemerkényi Ágnes (szerk.): Folklór és nyelv. (Folklór a magyar művelődéstörténetben) Akadémiai Kiadó, Budapest, 313-34.

Gulyás Judit 2011a. A magyar folklorisztika előzményei (1782-1848). In: Paládi-Kovács Attila (fószerk.): Magyar néprajz I/1. Táj, nép történelem. Akadémiai Kiadó, Budapest, $127-42$.

Gulyás Judit 2011b. Hitelesség, hamisítás, textualizáció. A Benedek Elek meséi kapcsán kialakult vita. In: Benedek Katalin (szerk.): A népköltészet teritett asztalánál. MTA Néprajzi Kutatóintézete, Budapest, 25-46.

Gulyás Judit 2015. A szóbeliség értéke, értelmezése és a folklorisztika önmeghatározása. In: Neumer Katalin (szerk.): Médiák és váltások. Identitások és médiák II. MTA BTK Filozófiai Intézet-Gondolat Kiadó, Budapest, 11-29.

Gyulai Pál 1865. Vörösmarty nyelvéröl. Koszorú III/23: 545-9.

Gyulai Pál 2008. A fordításról. In: Józan Ildikó (szerk.): A müforditás elveiről. Magyar fordításelméleti szöveggyüjtemény. Balassi Kiadó, Budapest, 240-6.

Harsányi István - Gulyás József (szerk.) 1922. Csokonai Vitéz Mihály összes müvei I-III. Genius, Budapest.

Hász-Fehér Katalin 2016. [Arany János széljegyzetei az Europa - Chronik der gebildeten Welt címü folyóiratban] A sorozatról és a jelen kötetröl. In: KoROMPAY H. János (szerk.): Folyóiratok 1. Lapszéli jegyzetek (kritikai kiad.). (Arany János Munkái 1.) Universitas MTA Bölcsészettudományi Kutatóközpont Irodalomtudományi Intézet, Budapest, 7-89.

Imre Sándor 1863. Kazinczy költészete. Koszorú I/10: 217-21.

Keresztury Dezső 1987. „Csak hangköre más” Arany János 1857-1882. Szépirodalmi Könyvkiadó, Budapest.

Máté Judit Eszter 2009. Egy magyar nyelvkönyv a 19. Század végéről. Josef Holtzmann: Metodischer Unterricht in der ungarischen Sprache (1880). THL2 - A magyar nyelv és kultúra tanításának szakfolyóirata 1/2: 49-57.

Mikó Imre, gróf 1863. A Koszorú. Koszorú I/1: 1-4.

Milbacher Róbert 2000. „...Földben állasz mély gyököddel...” A magyar irodalmi népiesség genezisének akkulturációs metódusa és pórias hagyományának vázlata. /(Doktori mestermunkák/) Osiris Kiadó, Budapest.

Miskolczy Amrus 2010. A nyelvújítási viták metapolitikája. Kazinczy az egyéni szabadságért. Forrás: Irodalom-Müvészet-Tudomány 42: 23-47.

Pelcz Katalin 2006. A nyelvi minták megjelenési formái a 19. századi magyar nyelvkönyvekben. THL2 - A magyar nyelv és kultúra tanitásának szakfolyóirata 1-2: 93-101.

Riedl Frigyes 1887. Arany János. Hornyánszky Viktor, Budapest.

Ruttkay Veronika 2016. Burns, Arany, Lévay - avagy népiesség és/mint fordítás. ItK-Irodalomtörténeti Közlemények CXX/1: 3-30.

Simonyi Zsigmond 1913. A magyar nyelv eredete és története. In: Ferenczi Zoltán (szerk.): A magyar irodalom története 1900-ig. Athenaeum Irodalmi és Nyomdai Részvénytársulat, Budapest, 1-18.

Szász Károly 1861. Külföldi népdalok Greguss Ágosttól, Kiadta a Kisfaludy-társaság. Szépirodalmi Figyelö 42: 660-2.

Tamás Ildikó 2018. Nyelvrokonság, müfordítás, népköltészet az Arany János által szerkesztett Szépirodalmi Figyelő és Koszorú hasábjain. Ethno-Lore: A Magyar Tudományos Akadémia Néprajzi Kutatóintézetének Évkönyve, 43-83.

Tolcsvai Nagy Gábor 2009. A különbözés egysége. Kazinczy nyelvértelmezésének funkcionális alapjai. Magyar Nyelv 105: 263-70. 
Tolcsvai Nagy Gábor 2010. A „népnyelv” a magyar nyelv történeti értelmezésében. In: Szemerkényi Ágnes (szerk.): Folklór és nyelv. (Folklór a magyar művelődéstörténetben) Akadémiai Kiadó, Budapest, 15-28.

Török Zsuzsa 2005. Ralph Waldo Emerson Arany János Szépirodalmi Figyelőjében (Adalékok az esszé 19. századi honosításának történetéhez). In: Imre László - Gönczy Monika (szerk.): Normakövetés és normaszegés 19. századi elméletekben és müfajokban. /(Studia Litteraria XLIII./) Debreceni Egyetem, Debrecen, 27-41.

Voigt Vilmos 2010. Nyelvjárás és folklór. Vannak-e és mióta magyar nyelvjárási szövegek? In: Szemerkényi Ágnes: Folklór és nyelv. (Folklór a magyar müvelődéstörténetben) Akadémiai Kiadó, Budapest, 147-160.

\title{
SZERZÖMEGJELÖLÉS NÉLKÜL HIVATKOZOTT FORRÁSOK
}

Reguly Antal hagyományai. Koszorú 1865/I, 2: 42-4; 1865/I, 3: 64-6; 1865/I, 4: 90-1. Budapesti Szemle (Irodalom címü rovatban). Koszorú 1864/I, 10: 234.

Vegyes rovat. Koszorú 1865/I, 4: 94.

\author{
Tamás Ildikó \\ tudományos munkatárs \\ Bölcsészettudományi Kutatóközpont \\ Néprajztudományi Intézet \\ MTA Kiváló Kutatóhely \\ https://orcid.org/0000-0003-1000-3873
}

\begin{abstract}
SUMMARY
Tamás, Ildikó

\section{Problematics of the national language in the context of language history, folk-poetry} and translation theory

In the literary journals edited by János Arany, I examine the reception of Kazinczy's language renewal concerning folklore, popular language and literary translations. The publication of the folk poetry and literature of other peoples inspired numerous questions, contemporary debates based on the importance of the language that embodies the "folk character" of a people/nation. The creation of the Hungarian literary language as an idealized mix of folk and elite literary style, and the reception of folk poetry and foreign literature were linked in many ways. The central issues of translation were "what should be translated?" and "should close translation, authentic interpretation, aesthetic interest, or educational intent be emphasized?". The adaptation of folk poetry to the literary tastes of that social environment, its correspondence with the needs of public education, and the practice of free rewriting in the mid-nineteenth century fit into a much broader, partly classicist and partly national discourse.
\end{abstract}

Keywords: language renewal, neologism, folk poetry, foreign literature, translation, folk text publishing, Hungarian literary language, standard 